\title{
FEBRA PALUDICĂ ÎN TRANSILVANIA ÎN A DOUA JUMĂTATE A SECOLULUI AL XIX-LEA. ASISTENȚA MEDICALĂ LA CONSTRUCṬIA CĂILOR FERATE ÎN REGIUNEA CLỦJ
}

\section{Horber Orsolya', Zilahi Karoly ${ }^{1}$}

${ }^{1}$ Societatea Civilă Medicală Praxis Dr.Horber-Dr.Zilahi

Address for correspondence / Adresa de corespondență:

e-mail: horberzilahi@zappmobile.ro

Title: Malaria Fever in Transylvania in the Second Half of the $19^{\text {th }}$ Century. The Sanitary Service in the Construction of Railwals in the Region of Cluj

\section{Abstract}

The construction of railways in the second half of the $19^{\text {th }}$ century represented an important stage in the modernization of Transylvania. The line Cluj-Razboieni spanning $69 \mathrm{~km}$ was made between 1871 and 1873. The city of Cluj/Kolozsvar was becoming at that time an important cultural and academic centre of the Austro-Hungarian Monarchy. Antal Genersich, the founder of the Institute of Pathological Anatomy in Cluj/Kolozsvar, had been the doctor working as a supervisor of the public health of the workers working at the railways. A disciple of Rokitansky and Virchow, Genersich was a great theorist but also a clinical doctor. He published the results in a Report in 1875. Genersich and colleagues treated 11.000 patients of which 6,525 suffered from malaria, this making it the most important disease. The region of Cluj was an area of endemic malaria and the epidemics caused serious depopulation. The Report includes recommendations on how to eradicate the disease: systematic river drainage, afforestation. Malaria appeared as a result of several major construction projects in the second half of the $19^{\text {th }}$ century: the construction of canals (Panama and Suez canals) and the construction of railways. The Paper presents the geological, geographical and climatic conditions of this area, the critical factors influencing the spreading of contagious diseases (especially malaria) in the community of railway workers of the line Cluj-Războieni and also the public health measures adopted in the fight against the disease.

Keywords: railways, sanitary service, malaria,Transylvania

Cuvinte-cheie: calea ferată, asistență medicală, malarie,Transilvania

\section{Construcția căilor ferate la periferia Europei în a doua jumătate a secolului XIX}

După revoluția din 1848 Transilvania devine o provincie condusă de Viena, iar din anul 1867 va face parte din monarhia Austro-Ungară. Economia ei se baza pe resursele munților Carpați (lemn, minerale, mine de aur, argint, fier şi sare), pe burghezia orăşenească, dar şi pe statutul de legătură, de drum comercial între Balcani şi Europa Centrală.

Drumurile au fost proiectate conform zonelor geografice şi construite mai ales în văile râurilor. Aceste văi erau corespunzătoare şi pentru construcția căilor ferate.

Legătura dintre capitalele monarhiei şi oraşele Transilvaniei devine foarte importantă în această perioadă. Astfel au existat două propuneri de linii: cea din valea Mureşului a fost favorizată de Viena 
(având în vedere centrul Transilvaniei în Sibiu, cu o populație majoritar săsească) şi cea de-a doua din valea Crişului Repede, care trecea prin Cluj, fiind patronată de Budapesta [4]. Viena câştiga în această luptă, dar doi ani mai târziu, Parlamentul de la Budapesta decide şi începerea construcției liniei Oradea-Cluj-Braşov. Clujul este în această perioadă un centru economic, comercial şi cultural al Transilvaniei, Universitatea Franz Joseph fiind înființată în 1872. Construcția liniei Cluj-Razboieni începe în primăvara anului 1871 şi se termină la sfârşitul anului 1873 . Calea ferată trece la est de oraşul Cluj prin Apahida, ulterior schimbă direcția spre sud, trece prin munți şi ajunge în depresiunea Arieşului, apoi în valea Mureşului. Trecând prin văi de râuri, construcția feroviară a presupus sistematizarea apelor, protecția malurilor şi cercetări geologice amănunțite. Clima şi zona geografică prin care trece calea ferată a pus probleme serioase pentru construcție.

\section{Serviciul sanitar la construcția căilor ferate în regiunea Cluj. Paludismul în Transilvania}

Deşi o altă boală contagioasă precum ciuma era aproape endemică în Transilvania începând cu secolul al XVI-lea, nici epidemiile de malarie nu erau rare. Samuel Hahnemann, întemeietorul homeopatiei, lucrând la Hermannstadt (Sibiu) pentru baronul Brukenthal în 1778-1779, se îmbolnăveşte de paludism, dar se vindecă repede [6].

Regiunea Cluj era o zonă de malarie, iar epidemiile frecvente au cauzat depopulări severe. Între anii 1871-1873, în timpul construcției căii ferate Cluj-Războieni, malaria a cauzat 45 de mii de zile de concediu medical, provocând mari pierderi societății constructoare.

Medicul anatomopatolog Antal Genersich de la Universitatea din Cluj a fost angajat, ca medic feroviar şi de medicina muncii, el supraveghind starea de sănătate a muncitorilor de pe şantier. Genersich era un mare teoretician, fiind discipolul lui Rokitansky şi Virchow, dar era şi un medic practicant şi clinician talentat. La construcția căii ferate el a tratat împreună cu colaboratorii săi peste 11.000 de cazuri, dintre care 6.525 cazuri erau de malarie [2].

După părerea lui Genersich absența pădurilor şi copacilor, zonele bogate în mlaştină, dar şi prezența minelor, produceau un climat similar cu delta râurilor („Brackwasser”). Astfel propagarea bolii devenea foarte rapidă.

Şase mii de muncitori au fost angajați de Societatea Căilor Ferate Ungare de Est şi pe parcursul a 29 luni de muncă numărul deceselor înregistrate a fost de 123. Bilanţul stării de sănătate şi angajarea muncitorilor era sarcina medicului de medicină ocupațională angajat de societatea de construcție. El călătorea frecvent (de trei ori pe săptămână de-a lungul căii ferate), tratând persoanele rănite, participând la depistarea bolilor profesionale şi contagioase. „Medicul căii ferate” avea decizia de a interna un pacient în spital (a existat un spital de campanie la Cojocna), având obligația de a preveni apariția, agravarea sau propagarea maladiilor prin măsuri preventive. Genersich a avut şi datoria de a efectua expertize medico-legale. În concluzie, el era un medic generalist, legist, de medicina muncii, adică un omnipractician, având responsabilitatea supravegherii sănătătii pacienților săi.

În această perioadă efectuează primele cercetări ştiințifice din Transilvania pe Anopheles microbiologul clujean Miklos Jancso de la Universitatea Franz Joseph. El a fost în corespondență şi cu Ronald Ross, experiențele lui Jancso fiind denumite de Ross ca "the admirable experiments of Jancso" [5]. La examinarea frotiului, cercetătorii din laboratoarele Universității din Cluj observă paraziți în globulele roşii, constatând că paraziții prezenți în sânge se divizează la intervale regulate (Jancso şi Rosenberger 1895) [1].

Genersich, medicul căilor ferate, a publicat rezultatele într-un raport în Jurnalul Societăţii Muzeului Ardelean (1875). Raportul conţinea recomandări pentru eradicarea bolilor: drenajul şi regularizarea apelor, extensia forestieră. Recomandările au fost puse în practică mai târziu prin legea sănătății publice: măsurile preventive şi curative adoptate împotriva paludismului (de exemplu chinina gratuită) au salvat mii de vieți. Cu toate acestea, la conferința anuală a Societății Muzeului Ardelean de la Turda în 1938, medicul Baumgarten Sandor de la Câmpia Turzii semnalează totuşi 
existența unor cazuri atipice de malarie din practica lui, oraşul fiind situat pe linia căii ferate ClujRăzboieni [3].

\section{Medicina și calea ferată în Transilvania. Consecințele economice și ecologice. Implicații culturale}

Construcția căilor ferate în Transilvania a accelerat dezvoltarea industrială, a însemnat locuri de muncă în regiune, accesul muncitorilor la servicii, inclusiv la cele medicale.

Se deschide o cale de acces a mărfurilor agricole la piețe, se formează relații comerciale între regiuni. Mişcarea oamenilor devine mult mai uşoară; educația şi cultura oraşelor devine accesibilă pentru mii de săteni.

Acțiunile conexe construcției (regularizarea apelor, ridicarea terenurilor) au efecte hidro-ecologice prin crearea coridoarelor biologice şi consecințelor climaterice.

Meseriile vechi, artizanale, dispar (printre care pescuitul, împletitul coşurilor), dar apar meserii noi în serviciul construcțiilor căii ferate.

Problemele de sănătate publică (bolile contagioase precum malaria, holera) apărute în timpul construcției căii ferate Cluj-Războieni nu sunt unice, epidemiile provocând mari pierderi societăților de construcții la căile ferate din Panama (Colon-Panama), sau din Suez. Însă construcția liniei ClujRazboieni a însemnat un punct de plecare pentru limitarea, iar mai târziu pentru eradicarea paludismului în Transilvania.

\section{Concluzii}

Una dintre consecințele construcției căii ferate (transportul modern în epoca revoluției industriale) prin impactul economic este schimbarea modului de viață.

Lupta între regiunile Transilvaniei pentru linii de căi ferate a fost intensă.

Pentru oraşele şi satele din Transilvania, la periferia Europei, construcția căii ferate a însemnat declanşarea unei perioade de creştere economică.

\section{Referințe}

1. Jancsó Miklós, Rosenberger Mór, Parasitologiai észleletek a kolozsvári belgyógyászati kórodan az 1894-ik évben elöordult malaria megbetegedéseknél, Értesitőaz Erdélyi Múzeum-Egylet Orvos Természettudományi Szakosztályából, XVII kötet, 1895, III füzet

2. Genersich, A, Jelentés a kolozsvári-kocsárdi vasútvonal épitesekor a munkásoknál elöordult megbetegedésekrö, 1875, Értesitő Erdélyi Múzeum-Egylet Orvos-Természettudományi Szakosztályából

3. Genersich, A, Emlékkönyv születésének 150 évfordulója alkalmából, Genersich Alapitvány Budapest,1994

4. T. Hámori Ferenc, Erdélyi vasút-Székely gyors, Indóház Kiadó, Budapest, 2008

5. Balint Nagy Istvan, Jancso Miklos in Paul de Kruif, Bacillusvadaszok, Guttenberg Konyvkiado Vallalat, Budapest

6. Tischner, R, Geschichte der Homeopathie, Verlag Dr.Willmar Schwabe, Leipzig, 1939

7. Horber, O, Zilahi, K, La fievre paludeenne en Transylvanie dans la deuxieme moitie du XIXe siecle. Le service sanitaire de la construction des chemins de fer dans la region Cluj (Poster presentation), V Reunion de la Societe Internationale d'Histoire de la Medecine, Sous l'egide du President de la Republique de Chypre, 9-12 september 2009, Nicosia, Cyprus 